\title{
The Most Common Patterns of Classroom Dialogue Used by Science Teachers in Omani Cycle Two Schools
}

\author{
Hanan Alshaqsi \\ Science Supervisor, Ministry of Education, Oman
}

\author{
Abdullah Ambusaidi \\ Prof., College of Education, Sultan Qaboos University, Oman, ambusaid@squ.edu.om
}

This study aimed to identify the patterns of classroom dialogue used by science teachers in science classes at Omani schools with respect to their gender. The study sample consisted of science teachers: three males and three females. To achieve the aims of the study, mixed methods with three instruments were used. These are an observation card or tool composed of items developed and divided into two domains: whole class dialogue and non-whole class dialogue. In addition, an interview was conducted in a sort of focus group and two lessons were video recorded. The study found that the most common patterns of science class dialogue were: teacher to student dialogue, teacher with student dialogue and teacher thinking with student dialogue. The least common patterns of science class dialogue were: student to student dialogue and all the kinds of non-whole classroom dialogue. The findings showed that female science teachers had better practices than male teachers in: Teacher to student dialogue, teacher with student dialogue and teacher thinking with student dialogue. Whereas there were no significant differences in student to student dialogue, individual work dialogue and group work dialogue, the whole sample didn't show any movement work dialogue between male and female teachers.

Keywords: classroom dialogue, whole classroom dialogue, non-whole classroom dialogue, science teachers, science classes

\section{INTRODUCTION}

Dialogue is one of the most powerful tools that teachers use to communicate with their students. It is the center of most of what happens in classrooms. Through talk, for example, concepts are explained, tasks are demonstrated, questions are posed, and ideas are discussed. Burbules, one of the most prominent researchers in dialogic methods, describes dialogue as a conversational interaction deliberately addressed to teaching and learning. He argues that not every conversation has a pedagogical purpose; and in reverse, that not all pedagogical communicative relationships are forms of conversation 
such as presentations (Burbules, 1999)

Vygotsky (1978) showed how learning was undertaken through largely linguistic interaction, with learner understanding depending on dialogue in a 'zone of proximal development'. However, this is not the case of some teachers. Some teachers according to Montgomery (2013) give more time to complete tasks related to developing their curriculum, planning to teach and assess their lessons, and grading student assessments to obtain data.

Due to the importance of dialogue in the classroom, several studies were conducted. For example, the study of Al-Mahrouqi (2010) focused on classroom talk characteristics from the Dialogicity perspective and found out that this characterization is related to students' learning. The study aimed particularly to reflect on and develop the concept of Dialogicity as a theoretical perspective for characterizing the nature of classroom talk in relation to both teaching and learning. The results of the study showed that there is a strong relationship between classroom talk dialogicity and teaching and learning. The researcher asserted that learning is closely connected to the classroom talk characterization from the dialogicity perspective, and does not stand in isolation from teaching.

Some studies, such as Peled-Elhanan \& Blum-Kulka (2006), identified three main genres of classroom discourse, differing in the degree of their dialogicity: 1) Socratic dialogue - a topical discussion where the final text is created by students and teacher in concert, 2) Pseudodialogue - in which the students are made to believe they are engaged in a topical discussion while being assessed on grounds of interpersonal relationships and mode, and 3) Monologue in the guise of a dialogue - in which the teacher asks topical questions while seeking the reproduction of his/her own text. The two latter ones were found to be dominant in the classes.

Other researchers such as Benus (2011) examined the patterns of dialogue that were established and emerged in one experienced fifth-grade science teacher's classroom that used the argument-based inquiry and the ways in which these patterns of dialogue and consensus-making were used toward the establishment of a grasp of science practice. $\mathrm{He}$ showed that the teacher principally engaged in three forms of whole class dialogue with students; talking to, talking with, and thinking through ideas with students. As time went on, the teacher's interactions in whole-class dialogue became increasingly focused on thinking through ideas with students, while at the same time students also dialogued more as each unit progressed.

In Harrison, (2006) study of the UK classrooms, it was noted that teachers control what is said and generally ask one-word-answer questions thereby slanting dominance of classroom dialogue in their favor. This practice has two effects: firstly, it limits the amount of expression and shared cognition among learners, and secondly it prohibits teachers from gaining adequate assessment of learners' existing knowledge base.

Scott, Mortimer, and Aguiar (2006) describe four types of classes based on the dialogue occurred (Table 1): 
a) Interactive/dialogic: Teacher and students consider a range of ideas.

b) Non-interactive/dialogic: Teacher revisits and summarizes different points of view, either simply listing them or exploring similarities and differences.

c) Interactive/authoritative: Teacher focuses on one specific point of view and leads students through a question and answer routine with the aim of establishing and consolidating that point of view.

d) Non-interactive/authoritative: Teacher presents a specific point of view.

Table1

Four Classes of Communicative Approach

\begin{tabular}{lll}
\hline & Interactive & Non-Interactive \\
\hline Dialogic & Interactive / Dialogic & Non-interactive / Dialogic \\
\hline Authoritative & Interactive / Authoritative & Non-interactive / Authoritative \\
\hline
\end{tabular}

Another classification of patterns of classroom dialogue is Whole Class Dialogue and non- Whole Class Dialogue (Benus, 2011).

- Whole-Class Dialogue includes:

1. Teacher talking to students: Teacher talking to students for a turn of talk that lasted usually more than 5 seconds. All students were asked or expected to be listening to the teacher. If student talk did occur during these moments it was infrequent and very short.

2. Teacher talking with students: Teacher was talking with students over several turns of talk (usually more than 15 seconds) to help students express or explain their thoughts about a particular idea. The teacher was helping students to hear the ideas of their classmates. The teacher pointed out what was stated from student talk as well.

3. Teacher thinking through ideas with students: Teacher was thinking through ideas with students over several turns of talk (usually more than 15 seconds) to help students think through their understandings. The teacher mentioned ideas that might not have directly come from students or bring together ideas from the past that were mentioned by students.

4. Student only talk: Students were talking to students over turns of talk that last usually more than 15 seconds. Students as a whole class talked to each other without the teacher talking.

- The Non- Whole Class Dialogue can be in: group work, individual work and movement wok.

The current study used this classification to investigate the most common patterns of dialogue among Omani science teachers.

Four major and three minor categories of teacher talk were found based on the study of Baker (2007). The major, or most frequent, categories of teacher talk included Teacher Feedback, Task Focusing, Setting the Learning, and Closed Questions. The minor or less frequent categories of teacher talk included Agency-Building, Promoting Thought and Connecting Learning. 


\section{Research Questions}

This study is the first study conducted in Omani context, which aims at investigating the patterns of classroom dialogue used by a sample of Omani science teachers. The study seeks to answer the following two research questions:

1. What are the common patterns of classroom dialogue used by Omani science teachers?

2. Are there any gender differences in the patterns of classroom dialogue used by Omani science teachers?

\section{METHOD}

\section{Research Design}

The study used mixed methods of collecting data. These are: Observation card or tool, focus group discussion and video recording. More detail about each tool is given below in study tools section.

\section{The Participants}

The participants were 6 science teachers ( 3 male teachers and 3 female teachers) selected intentionally by the researchers. They were selected from one educational Governorate in Oman. These teachers taught general science in grades (5-10). Targeted sample technique was used as teachers were chosen after their approval to allow the researchers to attend their lessons and make observation about their teaching. In addition, these teachers agreed to video record their lessons. Most studies in classroom dialogue focused on one teacher and attending more lessons. In the current study, the researchers covered more teachers with more classroom lessons attending. Each teacher was observed two times. In addition, the researchers analysed the two lessons that were recorded by the first author and well - trained science supervisor. Finally a focus group interviews with all teachers were conducted in separate sessions, one for male teachers and another one for female teachers.

\section{Data Collection}

In order to investigate the patterns of classroom dialogue, three study tools were used including the observation card, video recording and teachers' interview. The observation card composed of (13) items. It was developed by the researchers after reviewing the previous researches especially the study by Benus (2011). The instrument was divided into two domains: whole class dialogue and non-whole class dialogue. The validity of the instrument was checked by three specialists in science education, one of them a university lecturer and the other two are school teachers. The judges were asked to assess the items in terms of clarity, suitability for the purpose of the study, and the appropriateness of the classification. Due to the judges' comments and suggestions, 3 items were omitted from the final version of the observation tool. The reliability value for the overall observation tool was $80 \%$ by using Cooper equation of inter-reliability (Cooper, 1975, 27). Table (2) shows the observation card items. 
Table 2

Items of the observation card

\begin{tabular}{lllll}
\hline No & \multicolumn{1}{c}{ Item } & & \\
\hline 1 & $\begin{array}{l}\text { The instructional strategies and activities respected } \\
\text { students' prior knowledge }\end{array}$ & Average 2 High 3 & Comments \\
\hline 2 & The teacher shows interest in the student's answers. & & \\
\hline 3 & $\begin{array}{l}\text { The teacher directs questions to the students in classroom } \\
\text { dialogue. }\end{array}$ \\
\hline 4 & $\begin{array}{l}\text { Students interact with the teacher about the subject based } \\
\text { on their knowledge and intellectual stocks. }\end{array}$ \\
\hline 5 & Teacher encouraged students to seek alternative solutions. & \\
\hline 6 & $\begin{array}{l}\text { Teacher encourages students to apply their learning in new } \\
\text { situations. }\end{array}$ \\
\hline 7 & $\begin{array}{l}\text { Students show their point of view using evidence and } \\
\text { explanations that support their opinion. }\end{array}$ \\
\hline 8 & $\begin{array}{l}\text { The focus and direction of the lesson was determined by } \\
\text { ideas originated with students. }\end{array}$ \\
\hline 9 & $\begin{array}{l}\text { Students talk with each other without any interruption from } \\
\text { the teacher. }\end{array}$ \\
\hline 10 & The teacher organizes group work in the lesson. & \\
\hline 11 & Students interact with the provided work. & \\
\hline 12 & The teacher organizes individual work. & \\
\hline 13 & The teacher organizes movement work. & \\
\hline
\end{tabular}

The observation card (tool) was ready to be implemented after the validity and reliability were checked. Before making any visit to selected teachers, the researchers assure to each teacher that the results that come out from the observation card will be treated confidentially.

The first researcher (author) attended six science classes with three female science teachers in grades seven, eight and nine. Each teacher was visited twice with an interval of two weeks between the first and second visit. The observation card was implemented in all lessons. The researcher (first author) sat at the back of the class and used the classroom dialogue observation card. One lesson of the second visit in grade seven was videorecorded.

For the male science teachers, a well-trained science supervisor conducted the observations. He attended six science lessons with three science male teachers. Each teacher was visited and observed two times in the classrooms he taught. In addition, the science supervisor video recorded of one lesson. The interview was conducted in a sort of focus group after analysing the observation cards. Focus group interview was conducted with male and female teachers. The first author conducted the focus group interview with female teachers, whereas a well - trained science supervisor conducted the focus group interview with male teachers. The interview with male teachers was conducted at a male school and the interview with female teachers was conducted in a female school. In both sessions, the same procedure and questions were used. The interview was conducted as follows:

1. Preparing the interview: The researchers determined the essential domains of discussion. They prepared the interview questions and the tools for gathering data. They 
also arranged time and place for the interview with the target teachers in coordination with the science supervisor and senior teacher at targeted schools.

2. Building a relationship with teachers and gaining their trust: The two interviewers introduced themselves to the focus group. They explained the aim of the interview and the reasons of selecting them. They clarified to the focus group that the data will be used for scientific purposes and will be dealt with confidentially in order to convince them to be engaged in the research.

3. Recalling information: in order to help teachers deliver data and exchanged ideas, the questions were asked in a clear and chronological way. Some of the questions asked have been planned for in advance, while other questions came up due to the teachers' responses. The discussion was flexible. Some of these questions were :

- When do you usually relate the previous taught knowledge with the knowledge being taught.

- When do you use students' dialogue with each other?

- Why is the teacher's talk more dominant?

- What are the advantages of students' thinking dialogue?

- What causes prevented group work activities?

- What challenges faced you in students' dialogue in group work?

- When do you use individual activities?

- What are the benefits of movement activities?

- What are the disadvantages of movement activities?

4. Recording teachers' responses: Data was collected during the discussion by writing. In addition, voice recording was also used to record any comments not written during the interview. The teachers' approval has been asked for.

The video recording was done in one lesson of each of the two teachers that were interviewed by the first author and the science supervisor. The recording was conducted after getting permission from both teachers. Moreover, the teachers were assured that their recordings will be analysed with high confidentiality. Then, the researchers analyzed the both recording and came out with some results related to classroom dialogue. The results were treated as supporting evidence to observation tool findings in the dissuasion part of the article.

\section{Data Analyses}

For the first research question, the mean score was calculated for each visit and then the total mean score was calculated for all teachers visited. For the second research question, percentage of each pattern of classroom dialogue between male and female teachers was calculated. The focus group interview and video recording were analyzed and used as a supporting evidence to the results of analyzing observation card.

\section{FINDINGS}

\section{Results of Research Question 1}

In order to determine the common patterns of classroom dialogue used by science teachers in Omani grades (5-10) schools, the observation card was analysed according to 
the two domains. The first domain is "whole class dialogue" which includes teacher's talk to students, teacher's talk with students, teacher's thinking through ideas with students and student to student talk. The second domain is 'non-whole classroom dialogue' which includes individual work, group work and movement work. The mean of each classroom visit for each teacher was calculated. In addition, the total mean of each domain and its component for all six teachers was calculated (Table 3 ). The range mean $(1.00-1.66)$ indicates low level of practices, while $(1.67-2.33)$ indicates average level of practices and $(2.34-3.00)$ indicates high level of practices.

Table 3

Mean of each pattern of classroom dialogue

\begin{tabular}{|c|c|c|c|c|}
\hline Classroom dialogue & Mean Value & Patterns of classroom dialogue & Mean & Level \\
\hline \multirow[t]{4}{*}{ Whole } & \multirow[t]{4}{*}{1.91} & Teacher's talk to students & 2.67 & High \\
\hline & & Teacher's talk with students & 2.00 & Medium \\
\hline & & Teacher's thinking through ideas with students & 1.94 & Medium \\
\hline & & Student to student talk & 1.04 & Low \\
\hline \multirow[t]{3}{*}{ Non-whole } & \multirow[t]{3}{*}{1.29} & Group work & 1.29 & Low \\
\hline & & Individual work & 1.58 & Low \\
\hline & & Movement work & 1.00 & Low \\
\hline
\end{tabular}

The results in Table 3 show that the most common patterns of classroom dialogue in whole classroom domain is teacher to student talk (2.67) then teacher with student talk (2.00) and teacher thinking with student (1.92) which both of them have medium level and finally student to student talk (1.04) with low level. For non-whole classroom domain, the most common is individual work (1.58), then group work (1.29), and finally movement work (1.00). All these types of dialogue received low level in teacher practices.

\section{Results of Research Question 2}

In order to determine gender differences in the patterns of classroom dialogue used by Omani science teachers, the percentages of each type of classroom dialogue were calculated for all science teachers participated in the study (3 male teachers and 3 female teachers) and are presented in Table 4.

Table 4

The percentage of each pattern of classroom dialogue

\begin{tabular}{lll}
\hline Patterns of classroom dialogue & \multicolumn{2}{l}{$\%$ of Practices } \\
\cline { 2 - 3 } & Male & Female \\
\hline Teacher to student talk & $21.64 \%$ & $35.99 \%$ \\
\hline Teacher with student talk & $11.71 \%$ & $33.12 \%$ \\
\hline Teacher thinking with student & $3.45 \%$ & $23.27 \%$ \\
\hline Student to student talk & $0 \%$ & $0 \%$ \\
\hline Group work & $63.20 \%$ & $7.62 \%$ \\
\hline Individual work & $0 \%$ & $0 \%$ \\
\hline Movement work & $0 \%$ & $0 \%$ \\
\hline
\end{tabular}

The results in Table 4 show that the Omani science female teacher has more patterns in classroom dialogue in three patterns. These are teacher to student talk, teacher with 
student talk and teacher thinking with student whereas the male teacher shows high percentage in group work. However, some patterns did not occur at all with male and female teachers.

\section{DISCUSSION}

Teacher to student talk was the main form of classroom dialogue used in the current study. This form was mainly used for three key factors; to warm-up classrooms, to clarify things and for classroom management. Usually, most science teachers start their lessons with warm- up using different methods such as questions or current event in the society. The warm-up attracts students' attention to the new lesson and helps organize their ideas and information. Warm-up is also used to move from one step to another step in the lesson. According to Ambusaidi and Al Belushi (2011), some warm- up resources are the hot issues shown in the newspapers and magazines and other media or school books. It clearly appeared in the observation as teachers were asking their students about previously learned information if it was related to the new lesson. The following scene in table (5) shows the questions asked by the teacher about the previous lesson and relating them to the lesson being taught

Table 5

Teacher to student dialogue in warm-up

\begin{tabular}{|c|c|}
\hline Dialogue & Person \\
\hline Teacher & $\begin{array}{l}\text { In the name of Allah the most Gracious, the most Merciful Peace and blessing } \\
\text { of Allah be upon the Prophet Mohammed. In the previous lesson we had a } \\
\text { wonderful lesson about mixtures. What are mixtures? Who can remind us? } \\
\text { What do mixtures mean? Yes Suleiman. }\end{array}$ \\
\hline Suleiman & They are two substances with each other \\
\hline Teacher & $\begin{array}{l}\text { They are what? Two substances.... together. Make a mixture of two } \\
\text { substances mixed together. We divided mixtures into two types (The teacher } \\
\text { is writing a mind map on the board). What are these two types? Amer }\end{array}$ \\
\hline Amer & Homogeneous mixtures and heterogeneous mixtures. \\
\hline Teacher & $\begin{array}{l}\text { Well-done! We divided mixtures (the teacher is writing on the board) into } \\
\text { heterogeneous mixtures and ... }\end{array}$ \\
\hline All classroom students & Solutions \\
\hline Teacher & $\begin{array}{l}\text { What do we call Homogeneous mixtures? (the teacher writes on the board) } \\
\text { What do we call Homogeneous? }\end{array}$ \\
\hline All classroom students & Homogenous \\
\hline Teacher & And separating ...... mixtures ? \\
\hline All classroom students & Heterogeneous. \\
\hline
\end{tabular}

Another reason for the dominant teacher to student talk in the classroom is the teacher's need to clarify things that are needed in the practical activities. Teacher to student talk tends to be monologue in order to summarize the main points of the activity, to clarify a problem or explain the safety during the practical work lessons. The researchers could 
identify this when they analysed the video recorded lessons. The teacher's voice was dominant during his/her distributing of the worksheets to the small groups and controlling the class to stop students' talking to each other, their laughing and comments. For example, one of the analysed scenes took 4 minutes and 25 seconds and it was the longest analysed part of teacher to student dialogue. The other forms of teacher to student dialogue were shorter. They took less than 50 seconds.

Male and female teachers declared during the focus group discussion (27/4/2016) that teachers give a lot of instructions due to classroom management problems such as too much laughter. Furthermore, some students move a lot to attract others' attention like standing up on the table. In addition, there are some health problems among students such as hearing or sight problems. Moreover, individual differences in one class force the teacher to use a lot of motivational as well as warning techniques to control the class. Teachers also repeat explanation to enable students of different levels to understand and follow the teacher. Another example is in Table 6 which presents a scene of teacher thinking with students' dialogue.

Table 6

Teacher thinking with students' dialogue in Grade Seven (Topic: Solutions)

\begin{tabular}{|c|c|}
\hline Person & Dialogue \\
\hline Teacher & $\begin{array}{l}\text { If we look at the substances with me here, come here Safiya.. you have two } \\
\text { substances ..mix them together and I want you to find out are they homogeneous } \\
\text { or heterogeneous? Oil.. OK ..water ..OK.. Stir them with glass rod. }\end{array}$ \\
\hline ...... & $\begin{array}{l}\text { Safiya came to the front of the class and held the beaker to mix oil and water and } \\
\text { then stir them together using glass rod. }\end{array}$ \\
\hline Teacher & Ok, what did I say? \\
\hline ..... & Safiya is mixing the oil and water \\
\hline Teacher & Allah bless you \\
\hline$\ldots \ldots \ldots \ldots$ & The teacher raises the beaker. \\
\hline Teacher & Now .. What did you observe Safiya? \\
\hline & Safiya is silent. \\
\hline Safiya & Heterogeneous \\
\hline Teacher & Why is it heterogeneous? \\
\hline ........... & Safiya is thinking. \\
\hline Teacher & Why is it heterogeneous? Does it appear as one substance or two? \\
\hline Safiya & Two substances \\
\hline Teacher & $\begin{array}{l}\text { Excellent Safiya. So when we mix oil with water, the mixture becomes } \\
\text { homogenous .. what? Homogeneous mixture. Why? Because the two substances } \\
\text { appear which are oil and water. Clear? }\end{array}$ \\
\hline
\end{tabular}

Although the focused group discussion with male and female teachers on (27 / 4 / 2016) showed that this form of dialogue is used in students' presentation and peer teaching, the researchers didn't find this form of dialogue in the two recoded lessons. It may exist in 
other lessons which were not receded. Student to student dialogue depends on the topic of the lesson. For example, this form of dialogue is used in the lesson about water and air in Grade six. From teachers' point of view, student to student dialogue is like peer teaching as the student explains some information provided him/her from the teacher to his/her peers. However, teachers do not prefer applying this way of teaching too much to avoid students' misunderstanding.

In this regard, three findings emerged from the study of Benus (2011) about science curriculum of grade five. The first finding, in both units (Living things and their environment, and Human body systems), teacher talked less as time went on and conversely student talk and activity increased as time went on. Second, in unit one the teacher was talking to, talking with, and thinking through students' ideas in approximately equal amounts. In the second unit about half of all teacher's talk was thinking through ideas with students while teacher talking and thinking through ideas remained equal. Third, in unit one when students talked without the teacher during whole-class conversation, $75 \%$ of the time the teacher's action involved the teacher talking to students.

In addition, comparing whole class dialogue with group work, it was found that the latter seemed to be a more effective method to implement dialogue in the classroom than the former (whole-class teaching). It is because students have more opportunities to talk to each other in small group (usually the group consists between 3-5 students). However, this is not the case in a whole classroom dialogue where the number of students per class is usefully around 38. The study by Schuitema, Veugelers, Rijlaarsdam \& Dam (2009) found that whole dialogue (average mean) has emerged more than non-whole classroom dialogue( low mean).

The least common type in the current research is non-whole dialogue. There are many factors behind this. The first factor is the stress that many teachers feel due to the too much science content to be covered compared to the allocated time to science subject in the semester. Teachers concentrate in their teaching to achieve the knowledge based learning outcomes and less time is given to high order thinking skills. The second factor is teachers' hesitance to start group dialogues in order to avoid not being able to control the class and feeling dissatisfied (Merecer, 2003). Al Qasabi (2013) pointed out that some teachers still don't have the foundation of successful dialogue and purposeful discussion which develop students' critical thinking.

The third factor is the number of students in the classroom. The biggest class size in the current study was 38 students. The outstanding students will do the task without involving the other students in the group. The interview with teachers highlighted that one of the reasons of teachers not using group work is the big number of students in class. This means that with big number, the group will be crowded and consequently, not all of the students can take part in the group work activities. As a result of this, there will be a limit in the number of students engaged in the dialogue.

Regarding the gender differences of most common classroom dialogue, Baran, Maskan \& Baran (2015) pointed out that female science teachers have abilities to teach science 
subject more effectively than male teachers. These results supported what was found in the current research that female teachers practice more forms of whole class dialogue than male teachers. In Omani situation, the female teachers encourage equal participation and creative expression for all students. If a student has difficulties in understanding the materials she is learning, female teachers can stop the lesson in order to focus on one student which is not understanding. Usually struggling students need teachers who can make learning fun, and they require the ongoing respect of teachers in order to stay motivated. Thus, female teachers like using different methods in classes such us learning by playing and storytelling. Female teachers owned the receptivity to change. When both female science teachers and male science teachers attend workshops in teaching methods as a training course, female teachers respond immediately and use these strategies in teaching their students. While few male teachers care about these strategies and try to implement them in their classes.

Male science teachers focus on science knowledge in classes. If there is practical lesson and the materials not there, they do not work hard to find alternatives and teach it theoretically. However, you can find some male teachers that try to borrow the tools and materials from the nearer schools and teach the practical part of the content.

Most Omani science teachers propose a question, typically one that is closed and requires students to recall a right answer or perform a quick calculation. Then often the first student to call out provides a one word or sentence response. The teacher reacts with a comment indicating whether the student's response is correct. The difference here is that female science teachers repeat the same question for others, but most of male science teachers move to the next idea or part of the lesson.

In Halpern's and others study (Halpern et al, 2007) about the cognitive differences between males and females found that females exceed males in linguistic and mathematical abilities as well as algebra and attainment tests. Women tend to be more talkative than men. However, males are better at body, visual and spatial abilities. Moreover, males also excel in extra-curricular application, spatial dimension and content skills. In the researchers observations of the six teachers, found that in the female teachers' dialogue they gave more instructions than male teachers either in class activities instructions or safety instructions in scientific discovery. Female teachers explain and repeat the same explanation and the same questions to a number of students. The male teachers on the other hand, tend to assign practical performance to students with few instructions giving them and give students the opportunity to discover the best way to do the practical activity.

Like other countries, Oman's education system is composed of 12 years Basic Education. It is divided into three cycles: cycle one (grades 1- 4), cycle two (grades 510 ), and finally cycle three (grades 11-12). In grades 1-10 the science curriculum is unified for all students and one science teacher teaches science to students. The boys and girls are separated in cycle two. For cycle three (grades 11-12), the school system is designed to prepare students for life after school; to enter higher education or for entry into the labour market. 
The gender difference in education achievement has become an international phenomenon. Gibb, Fergusson \& Horwood (2008) argued that over the last decade there has been evidence of a gender gap in educational achievement in a number of developed countries. Educational statistics have indicated that female teachers and students are outperforming males at all levels of the school system, attaining more school and postschool qualifications, and attending university in higher numbers.

In the Omani school leaving examination (General Education Diploma in Oman for Grade 12) in 2012-2013 for example, the results of students showed that the pass rate for girls students $(83 \%)$ was almost twice that of boys (43\%). The Omani Ministry of Education carried out a national assessment among a sample of students from grades 4, 7 and 10 in the years 2007 and 2008. In all these grades the female students outperformed male students in all subjects by very substantial margins (Ministry of Education/ World Bank, 2010).

Oman also participated in the Trends in International Mathematics and Science Study (TIMSS) in 2007, 2011 and 2015. In 2007, for example, girls outperformed boys in Mathematics by 54 points, the largest differences between genders among the 48 participant countries. In science, girls outperformed boys by 61 points, making Oman the country with the third largest score differences between girls and boys (Ministry of Education/ World Bank, 2013).

In Oman, grades 5 to 12 the girls and boys have separate schools and the teachers in boys' schools are all male. It seems that one of the factors behind the boys' underachievement is that girls tend to use their time after school more constructively than boys, for example by reading for enjoyment or doing homework (Ministry of Education/ World Bank, 2013). Another factor which may be the reason of gender difference in achievement is that female Omani science teachers tend to use different types of classroom dialogue more than male do which affects the students' achievement. In this regard, Schwartz (2010) argued that one of the important factors related to students' learning at school is teaching and classroom dialogue is the heart of teaching. Moreover, Al-Mahrouqi (2010) pointed out that learning is closely connected to the classroom talk characterization from the Dialogicity perspective, and does not stand in isolation from teaching.

In the light of the above results the study recommends the importance of using all patterns of classroom dialogue as effective teaching strategies and the necessity of appropriate training for science teachers to introduce the whole dialogue patterns and non- whole classroom dialogue patterns. In addition, the study recommends the incorporation of the kinds of classroom dialogue in teacher's manual to teach science curriculum and to train the supervisors about these pattern so they will be able to train their teachers.

More research should be conducted to find out the impact of using different types of classroom dialogue on student achievement and a similar research to this one with other variables such as type of years of teaching experience and teachers' attitudes to teach science should be done. 


\section{REFERENCES}

Al-Mahrouqi, A. S. (2010). Characterizing the dialogicity of classroom talk: Theoretical and empirical perspectives. Unpublished Dissertations, University of Leeds, UK.

Al Qasabi, F. (2013). Types of Questions Asked by Grade Ten Basic Students in Science Subject According to Harlin Taxonomy. Unpublished Master Thesis, Sultan Qaboos University, Sultanate of Oman

Ambusaidi, A., \& Al Belushi, S (2011). Teaching Science Methods: Concepts and Practical Applications. Amman: Al Maseerah Publisher.

Baker, J. E. (2007). Teacher Talk, Teaching Philosophy, and Effective Literacy Instruction in Primary-Grade Classrooms. Unpublished Dissertation, Tennessee Technological University, USA.

Baran, M., Maskan, A., \& Baran, M. (2015). Physics, Chemistry and Biology Teachers' Reasons for Choosing the Profession of Teaching and Their Levels of Job Satisfaction with Respect to Certain Variables. Journal Of Education and Training Studies, 3(3), 101-110.

Benus, M. J. (2011). The Teacher's Role in the Establishment of Whole-Class Dialogue in a Fifth Grade Science Classroom using Argument-Based Inquiry. Unpublished Thesis, University of Iowa, USA.

Burbules, N. C. (1999). Dialogue in Teaching: Theory and Practice. New York: Teachers College Press.

Cooper, J. (1975). Measurement and Analysis of Behavior Techniques. Ohio, Charles, E, Mexil, Columbus.

Halpern, D. F., Benbow, C. P., Geary, D. C., Gur, R. C., Hyde, J. S., \& Gernsbacher, M. A. (2007). The science of sex differences in science and mathematics. Psychological Science in the Public Interest, 8(1),1-51.

Harrison, C. (2006). Banishing the quiet classroom. Education Review, 19(2), 67-77.

Mercer, N. (2003). The educational value of 'dialogic talk' in 'whole-class dialogue'. Retrieved 2015,Feb 6 from: http: dera.ioe.ac.uk/6062/

Montgomery, H. N. (2013). Teacher Dialogue and its Relationship to Student Achievement. Unpublished Thesis, The University Of Southern Mississippi, USA.

Peled-Elhanan, N., \& Blum-Kulka, S. (2006). Dialogue in the Israeli classroom: Types of teacher-student talk. Language and Education, 20(2), 110-127 .

Gibb, S.J, Fergusson, D. M., \& Horwood, L.J (2008) Gender Differences in Educational Achievement to Age 25. Australian of Journal of Education, 52(1), 63-80

Schwartz, B. (2010). Strategic priorities for school improvement. Harvard Education Press. 
Schuitema, J., Veugelers, W., Rijlaarsdam, G., \& Dam, G. t. (2009). Two instructional designs for dialogic citizenship education: An effect study. British Journal of Educational Psychology, 79(3), 439-461.

Scott, P. H., Mortimer, E. F., \& Aguiar, O. G. (2006). The tension between authoritative and dialogic discourse: A fundamental characteristic of meaning making interactions in high school science lessons. Science Education, 90(4), 605-631.

Ministry of Education/World Bank (2013). Education in Oman: The Drive for Quality. Muscat, Sultanate of Oman .

Vygotsky L. S. (1978). Mind in society: the Development of higher psychological processes. Cambridge, Massachusetts: Harvard University Press. 